\title{
Newcastle Disease Virus (NDV) Iraqi Strain AD2141 Induces DNA Damage and FasL in Cancer Cell Lines
}

\author{
Ahmed M. Al-Shammary \\ Iraqi Center of Cancer and Medical Genetics Research (ICCMGR) \\ Al-Mustansiria University, Iraq \\ Tel: 964-780-9143-3825Ｅ-mail: Ahmed.Al-shammari@iccmgr.org
}

Hayfa H. Hassani (Corresponding author)

Department of Biology, College of Science, University of Baghdad, Baghdad, Iraq

Tel: 964-780-161-9474Ｅ-mail: haiphahassani@gmail.com

Ula A.J. Ibrahim

Department of Biology, College of Science, University of Baghdad, Baghdad, Iraq

Tel: 964-790-160-4427Ｅ-mail: ulajaleel_2006@yahoo.com

Received: August 3, 2013 Accepted: August 17, 2013

doi:10.5296/jbls.v5i1.4081 URL: http://dx.doi.org/10.5296/jbls.v5i1.4081

\begin{abstract}
The oncolytic viruses are promising form of cancer therapy which is based on the selectively killing of the cancer cells. This study was aimed to investigate the role of Newcastle disease virus (NDV) Iraqi strain AD2141 in apoptosis. Firstly, the virulence of AD2141 was detected in embryonated chicken eggs after $48 \mathrm{hrs}$ of infection. It was observed a hemorrhage in the skin of infected embryos that led to death. Then, the ability of this strain for regression cancer cell lines was examined. By using cytotoxicity test, it was found $128 \mathrm{HAU} / \mathrm{ml}$ of AD2141 had a potent inhibition against growth of RD and AMN3 after $72 \mathrm{hrs}$ of exposure time; the inhibition rate was $86.8 \%$ and $86.98 \%$ respectively. Moreover, the apoptotic activity of AD2141 was examined by comet assay. A significant induction of DNA damage in cancer cells was determined after $48 \mathrm{hrs}$ of exposure time; the average DNA tail length in RD, AMN3, and AMGM was 55.46, 79.1, and 84.4 respectively, and the percentage of apoptosis in treated RD, AMN-3, and AMGM was 78\%, 92\%, and 94\% respectively. Furthermore, the concentration of
\end{abstract}


FasL in treated and untreated cells was measured by immunofluoresent technique. FasL was elevated particularly in treated human cancer cell lines, RD and AMGM; it was $62.5 \mathrm{pg} / \mathrm{ml}$ and $31.25 \mathrm{pg} / \mathrm{ml}$ respectively. From these results, it can be concluded that NDV Iraqi strain AD2141 is a velogenic type; it caused death in infected chicken embryos. In addition it is an oncolytic virus due to induced apoptosis by damaging DNA and elevating FasL concentration in human cancer cells.

Keywords: Newcastle Disease Virus, Apoptosis, FasL, Comet assay

\section{Introduction}

Newcastle disease virus (NDV) is a paramyxovirus and viruses from this family are enveloped, non-segmented, negative-sense RNA viruses, which causes the inflammation of respiratory and gastrointestinal tracts in a wide variety of poultry species (Kaleta \& Baldauf, 1988; Mayo, 2002).

Several strains of NDV have raised considerable interest in recent years for clinical application because of their oncolytic properties. NDV had an interesting immune stimulatory and anti-tumor activity. Schirmacher et al. (2000) investigated the capacity of NDV to activate anti-tumor activity in murine macrophages in vitro and in vivo; it was found that repeated intravenous transfer of NDV activated macrophages exerted a significant suppressive effect on pulmonary metastases in a mammary carcinoma tumor model as well as in a lung carcinoma model. In another study, a locoregional application model for treatment of liver metastases of luciferase transfected CT26 colon carcinoma cells was used. It showed that NDV strain MTH-68/H revealed a significant delay in tumor growth, as well as prolonged survival (Apostolidis et al., 2007). Schirrmacher \& Fournier (2009) indicated that the strong interferon response of normal cells upon contact with NDV appears to be the basis for the good tolerability of the virus in cancer patients and for its immune stimulatory properties, whereas the weak interferon response of tumor cells explains the tumor selectivity of replication and oncolysis. In recent studies, Hemagglutinin-neuramindase (HN) as a potential molecular immune adjuvant in tumor suppression was used (NI et al., 2011; Hui-fan et al., 2013). It was observed the replication of a plasmid encoding the Hemagglutinin-Neuraminidase (HN) protein of Newcastle Disease Virus $(\mathrm{pHN})$ in stimulation innate anti-tumor activity in tumor-bearing mice. The results indicated an induction of higher levels of systemic interferon- $\alpha$ and reduction tumor growth in the prophylactic mammary carcinoma DA3 tumor model in comparison to application of a control plasmid not encoding the HN protein. In this study, an attempt was done to investigate the role of Iraqi strain of NDV AD2141 in induction of DNA fragmentation and elevation of FasL concentrations in cancer cell lines.

\section{Methods}

\subsection{Preparation and Propagation of NDV Strain AD2141}

Newcastle disease virus Iraqi strain AD2141 was kindly provided by experimental therapy department, Iraqi Center for Cancer and Medical Genetic Research (ICCMGR). It was directly thawed and then antibiotic solution $(200 \mu \mathrm{g} / \mathrm{ml}$ Ampicillin and $200 \mu \mathrm{g} / \mathrm{ml}$ Streptomycin) was added to the virus sample. The sample was centrifuged at $2555 \mathrm{rcf}$ for $30 \mathrm{~min}$ at $4^{\circ} \mathrm{C}$. The 
supernatant was injected into 10-day embryonated chicken eggs, and the allantoic fluid was harvested, aliquot in small tubes, and stored at $-20^{\circ} \mathrm{C}$ until use. To propagate AD2141, $0.1 \mathrm{ml}$ of allantoic fluid was injected into each 10-day embryonated chicken eggs and the puncture hole in the egg was covered with paraffin. Eggs were incubated at $37^{\circ} \mathrm{C}$ in a humidified incubator and checked daily for embryo's death. Immediately after the death of embryo, it was transferred to the refrigerator. After $24 \mathrm{hrs}$ the allantoic fluid was collected by sterile syringe, purified from debris and erythrocytes, and then it was dispensed into small tubes and stored at $-20^{\circ} \mathrm{C}$. The virus was further passaged in embryonated eggs in which high titers of virus can be recovered (McGinnes et al., 2006; Al-Shammary, 2003).

\subsection{Cells and Cell Culture}

Three cancer cell lines, human pelvic rhabdomyosarcoma (RD), human cerebral glioblastoma-multiforme (AMGM), and murine mammary adenocarcinoma (AMN3) were kindly provided by ICCMGR (Baghdad, Iraq) and used throughout this study. AMN3 and AMGM were propagated and maintained on Rosswell Park Memorial Institute medium (RPMI-1640, US biological, USA), while RD cultured on minimal essential medium (MEM, Sigma) (Freshney, 2002). To these media, 10\% fetal bovine serum (Cellgro, USA) and 1\% penicillin/streptomycin (Cellgro, USA) were added and incubated in a humidified $5 \% \mathrm{CO}_{2}$ incubator (Heracell 150, Thermo Electron Corp.) at $37^{\circ} \mathrm{C}$. The cells were subcultured after they had achieved 80-90\% confluency which can be observed under inverted microscope (Nicon Eclipse TS100). Cell viability was assessed by using trypan blue (Pharma, Sweden) exclusion test and found to be greater than 99\% (Phelan, 1988).

\subsection{Cytotoxicity Measurement of NDV AD2141}

The cytotoxicity of NDV AD2141 on cancer cell lines was examined according to the inhibition of proliferation rate (IR \%) (Xu-Dong et al. 2009). Briefly, $2 \times 10^{4}$ cell $/ \mathrm{ml}$ exponentially growing cells were seeded in 96-well microculture plates with different titers of $\operatorname{NDV}(0.5,1,2,4,8,16,32,64,128 \mathrm{HAU} / \mathrm{ml})$ in $100 \mu \mathrm{l}$ and incubated at $37^{\circ} \mathrm{C}$ for $72 \mathrm{hrs}$. After incubation, $20 \mu$ l of MTT [3-(4, 5- dimethylthiazol-2-yl-2-2.5- diphenyltetrazolium bromide)] was added and incubated for further $3 \mathrm{hrs}$ at $37^{\circ} \mathrm{C}$. The untreated cells were also done as control. The absorbance of treated and untreated cells was measured at $492 \mathrm{~nm}$. The inhibitory rate of cell proliferation was calculated according the equation: $\mathrm{IR} \%=\mathrm{A}-\mathrm{B} / \mathrm{A} \times 100$; where $\mathrm{A}$ represents the absorbance of untreated cells, while $\mathrm{B}$ represents the absorbance of treated cells. The results of IR\% was plotted on Y-axis while the titers of NDV where plotted on X-axis. From the plotted curve, the $\mathrm{IC}_{50}$ of NDV can be measured (Stover, 2002).

\subsection{Detection of DNA Damage by Comet Assay}

The comet assay, also called the single-cell gel electrophoresis (SCGE), was performed as described by Jagetia and Rao (2011). Briefly; pre-cold microscopic slides were overlaid with $110 \mathrm{ml}$ of $0.5 \%$ normal melting agarose at $60^{\circ} \mathrm{C}$. The slides were immediately covered with a cover slip and then kept at $4^{\circ} \mathrm{C}$ for 15 minutes to allow the agarose to solidify. A volume of 10 $\mu \mathrm{l}$ of untreated cells (RD, AMN-3, and AMGM) or cells treated with NDV strain AD2141 (according to $\mathrm{IC}_{50}$ ) in $40 \mu \mathrm{l}$ of PBS were mixed with an equal amount of $1 \%$ lower melting 
agarose to form a cell suspension. After gently removing the cover slip, the cells suspension were added onto the first agarose layer and maintained at $4^{\circ} \mathrm{C}$ for 15 minutes to solidify. After removal of the cover slips, a volume of $80 \mu \mathrm{l}$ of low melting point agarose added to the slides, then covered with cover slip and left to completely dry. After drying, the slides were immersed in fresh prepared cold lysing solution $(2.5 \mathrm{M} \mathrm{NaCl}, 100 \mathrm{mM} \mathrm{Na} 2 \mathrm{EDTA}, 10 \mathrm{mM}$ Tris, $\mathrm{pH}$ 10.0, and $1 \%$ sodium sarcosinate) with $1 \%$ Triton $\mathrm{X}-100$ for 40 minutes at $4{ }^{\circ} \mathrm{C}$. The slides were then placed in a horizontal gel electrophoresis tank filled with fresh electrophoresis solution (1 $\mathrm{mM}$ $\mathrm{Na}_{2}$ EDTA and $300 \mathrm{mM} \mathrm{NaOH}, \mathrm{pH} \mathrm{13)}$ for 10 minutes. The slides were then placed in Tris-buffer (0.4 M Tris, $\mathrm{pH} 7.5)$ for $15 \mathrm{~min}$ to neutralize the excess alkali. After electrophoresis at $4{ }^{\circ} \mathrm{C}$, the slides were stained with $75 \mu \mathrm{l}$ of ethidium bromide for 30 minutes and were examined under fluorescent microscope (40 x magnifications). The quantization of SCGE data was analyzed by comet score software (TriTekCrop, Virginia, USA) (Nandhakumar et al. 2011). A total of 50 cells were scanned per each treatment and the length of DNA migration in the comet tail was quantified according to equation: Comet tail length=Maximum total length-head diameter, while the frequency of migration cells was calculated according to the equation: \% frequency $=$ No. cells with comets/ total scored cells $\times 100$

\subsection{Detection of FasL by Immunofluorescence}

The cell-surface ELISA method was used for detection FasL's level in the cells RD, AMN3, and AMGM. Briefly; the cell were seeded individually at $\sim 2 \times 10^{5}$ cells $/ \mathrm{ml}$ in 96 well plates and incubated at $37^{\circ} \mathrm{C}$ for $18 \mathrm{hrs}$ to get monolayer. According to the $\mathrm{IC}_{50}$, the growing cells were treated with $2 \mu \mathrm{l}$ of $\mathrm{AD} 2141$ for $1 \mathrm{hr}$ at $37^{\circ} \mathrm{C}$. After incubation, the cells were rinsed with PBS containing $1 \%$ fetal bovine serum and $0.1 \% \mathrm{NaN}_{3}$. The supernatant of treated cells were collected by centrifugation at $390.6 \mathrm{~g}$ for 5 min and Human cell monolayers, RD and AMGM, were incubated overnight at $4^{\circ} \mathrm{C}$ with anti-FasL specific antibody (G247-4; Pharmingen, UK) while murine cell monolayer AMN3 was incubated with monoclonal anti-FasL specific antibody (A11; Alexis Biochemical, UK) for 1 hour at room temperature. For control, irrelevant isotype antibodies were used. FasL was measured with an ELISA kit according to the manufacturer's instructions (Assay Design, Inc, Ann Arbor, MI, USA). Cells were analyzed with an ELISA reader (Asys Expert Plus, HyTech, Austria) at 405nm and compared with standard curve (Ryan et al. 2006; Sanchez et al. 2012).

\subsection{Statistical Analysis}

Data were expressed as mean \pm SD. Student t-test was used to analyze the numeric data. The differences were considered statistically significant when $\mathrm{p}<0.05$.

\section{Results}

\subsection{Virulence of NDV Strain AD2141 in Embryonated Chicken Eggs}

The embryonated chicken eggs were used to examine the virulence of NDV AD2141 (Figure 1). 


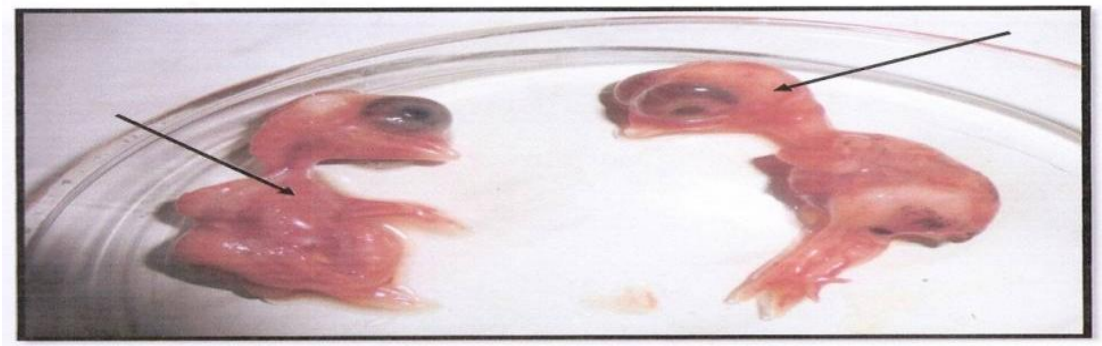

Figure1. Hemorrhage of skin in chicken embryos (black arrows) after 48 hrs of infection by NDV Iraqi strain AD2141.

The hemorrhage in the skin of infected embryos was clearly observed and death was occurred after $48 \mathrm{hrs}$ of injection.

\subsection{Cytotoxicity of NDV AD2141 on Cancer Cell Lines}

The inhibitory effect of several titers of NDV strain AD2141 on cancer cell lines (RD, AMN3, and AMGM) was detected (Figure 2, 3, and 4).

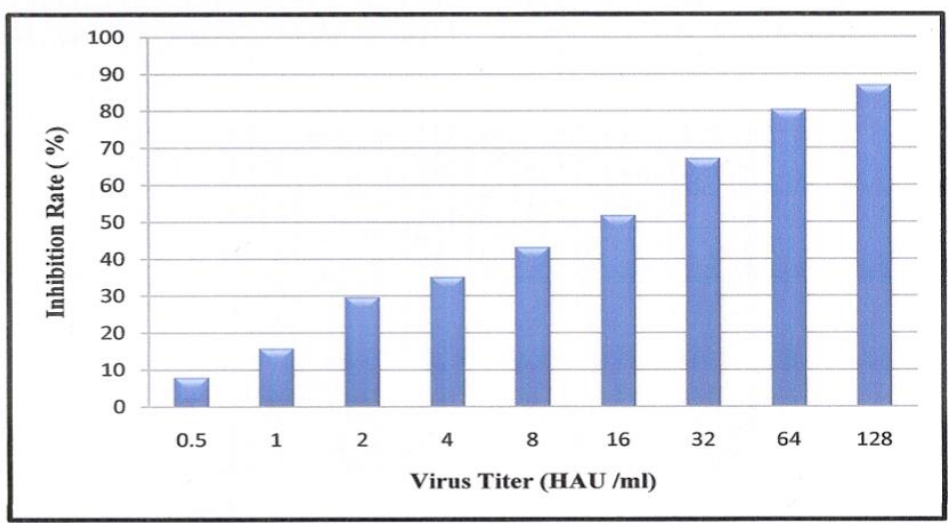

Figure 2. Inhibition growth of RD cells treated with various titers of NDV Iraqi strain AD2141 for $72 \mathrm{hrs}$ at $37^{\circ} \mathrm{C}$

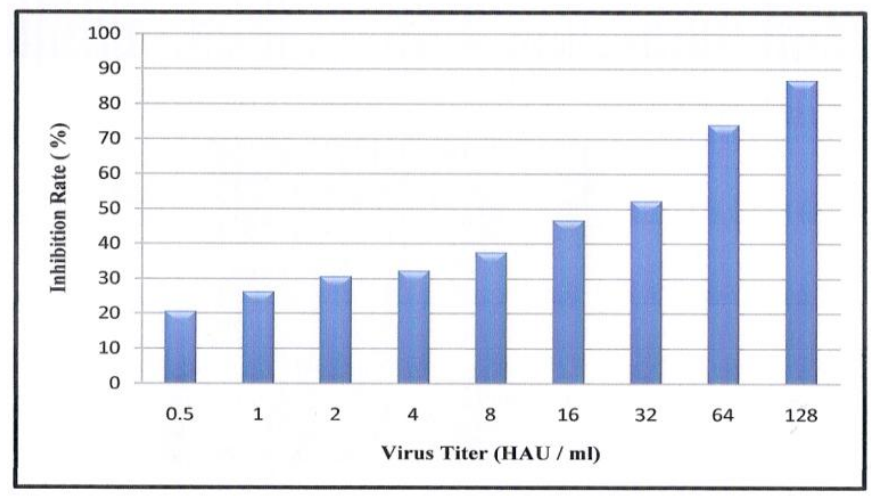

Figure 3. Inhibition growth of AMN3 cells treated with various titers of NDV Iraqi strain $\mathrm{AD} 2141$ for $72 \mathrm{hrs}$ at $37^{\circ} \mathrm{C}$ 


\section{Macrothink Institute $^{\mathrm{TM}}$}

It was found that the proliferation of cancer cells was inhibited by increasing the titer of this virus. Notable, $128 \mathrm{HAU} / \mathrm{ml}$ of this strain was effective to inhibit growth of RD and AMN3 after $72 \mathrm{hrs}$ of exposure time; the inhibition rate (IR \%) was $86.8 \%$ and $86.98 \%$ respectively (Figure 2 and Figure 3).

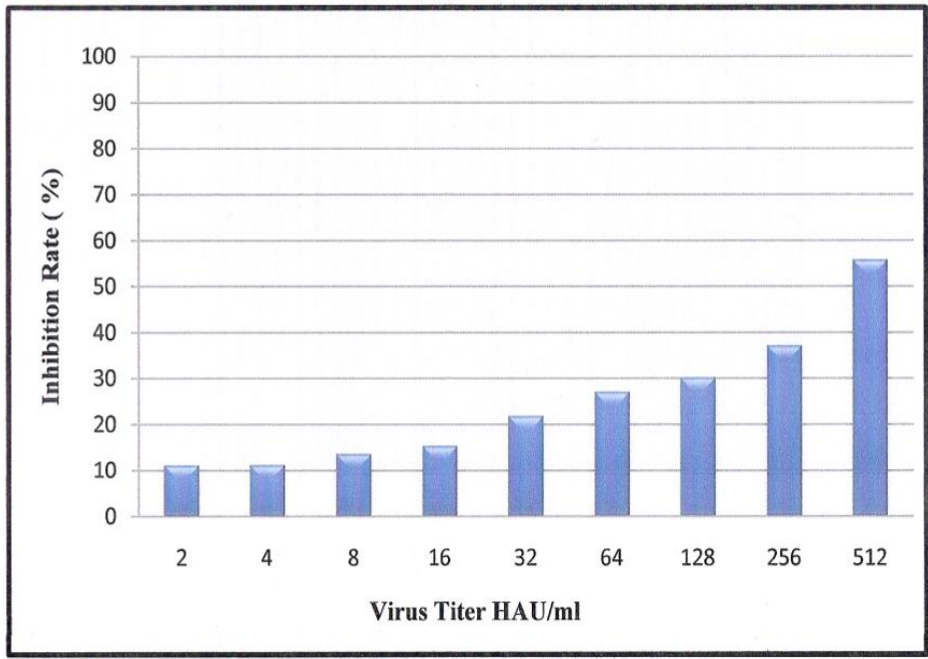

Figure 4. Inhibition growth of AMGM cells treated with different titers of NDV Iraqi strain AD2141 for 72 hrs at $37^{\circ} \mathrm{C}$

Whereas this strain exhibited low inhibition efficacy against growth of AMGM (Figure 4) in comparison with other cell lines used in this work, the result showed that higher titer of NDV AD2141, 512HAU/ml, was able to inhibit the growth by $55.66 \%$.

According to the dose-dependent Inhibition rate of cell growth, it was estimated that $\mathrm{IC}_{50}$ was $16 \mathrm{HAU} / \mathrm{ml}$ for both RD and AMN3, and 440HAU/ml for AMGM. These titers were used for further study.

\subsection{NDV AD2141 Induces Apoptosis}

\subsubsection{NDV AD2141 Induces DNA Damage in Cancer Cell Lines}

The ability of NDV AD2141for induction DNA fragmentation in cancer cell lines was investigated (Table 1).

Table1. DNA damage in cancer cell lines treated with NDV AD2141 expressed by tail length

\begin{tabular}{|c|c|cr|}
\hline Types of cell line & No. of scored cells & \multicolumn{2}{|c|}{$\begin{array}{c}\text { Average of DNA tail length } \\
\text { treated cells } \\
\text { untreated cell }\end{array}$} \\
\hline RD & 50 & $55.46 \pm 2 *$ & $16.08 \pm 2$ \\
\hline AMN-3 & 50 & $79.1 \pm 1^{*}$ & $12.24 \pm 1$ \\
\hline AMGM & 50 & $84.4 \pm 2 *$ & $14.8 \pm 2$ \\
\hline
\end{tabular}

*Shows significant value at $\mathrm{p}<0.05$ 


\section{Macrothink}

This strain was significantly $(\mathrm{P}<0.05)$ achieved DNA damage in cancer cell lines in comparison with untreated cells; the average of DNA tail length in RD, AMN-3, and AMGM was $55.46,79.1$, and 84.4 respectively.

Notable, the cells (RD, AMN-3, and AMGM) with damaged DNA demonstrated an increasing length of DNA migration from nucleus generating a comet shape (Fig. 5a, b, and c) whereas untreated cells had an intact nucleus (Figure.5 d, e, and f).
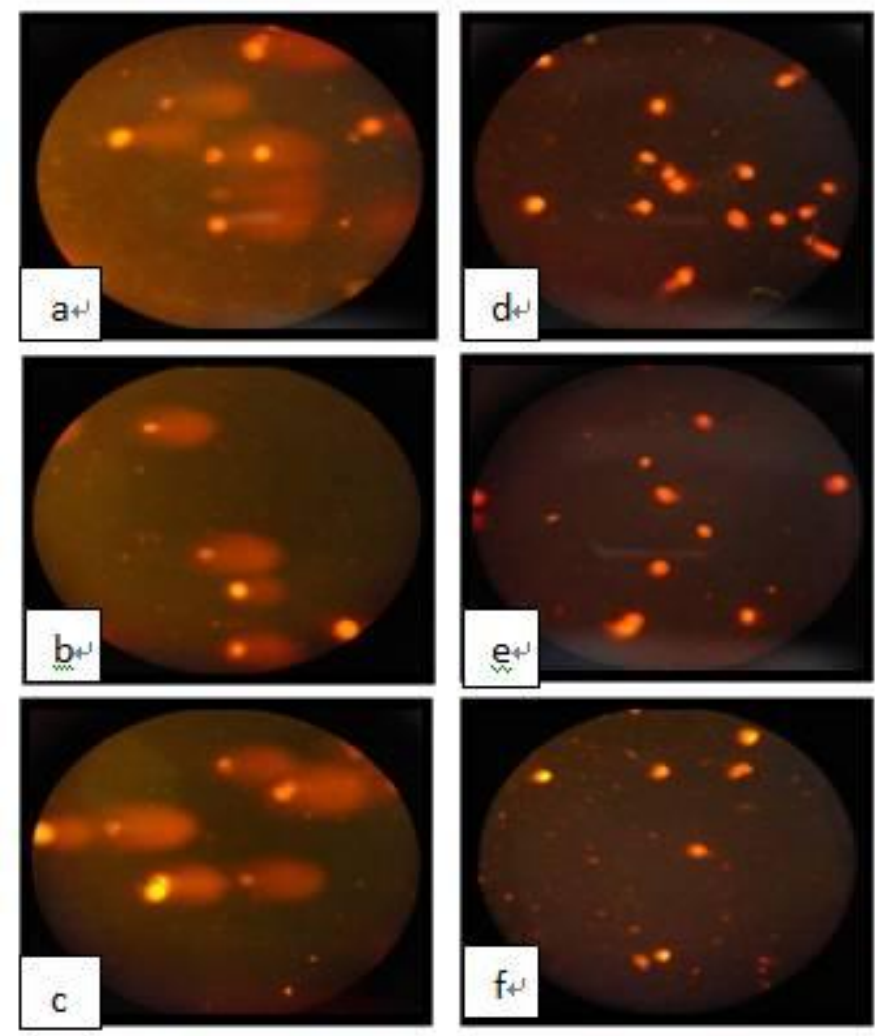

Figure 5. DNA damage in cancer cell lines by Comet assay. The DNA damage in the RD,

AMN-3, and AMGM cells treated with AD2141 represents by the letters a, b, and c respectively. Whereas the intact nucleus in the untreated cells of RD, AMN-3, and AMGM represents by letters $d, e$, and $f$ respectively.

On the other hand, the percentage of damaged cells was examined (Table 2).

Table 2. Frequencies of damaged cells in the treated and untreated cells with NDV Iraqi strain AD2141

\begin{tabular}{|c|c|}
\hline Types of Cell line & $\begin{array}{l}\% \text { frequency of damaged DNA in } \\
\text { treated cells } \quad \text { untreated cells }\end{array}$ \\
\hline $\mathrm{RD}$ & $78 \pm 1 * \quad 4 \pm 1$ \\
\hline AMN-3 & $92 \pm 1 *$ \\
\hline AMGM & $94 \pm 2 *$ \\
\hline
\end{tabular}

* shows the significant differences at $\mathrm{p}<0.05$ 
The results showed a significant increase $(\mathrm{P}<0.05)$ in the percentage of apoptosis in treated cells RD, AMN-3, and AMGM when compared with untreated cells and the percentage of damaged cells were $78 \%, 92 \%$, and $94 \%$ respectively.

\subsubsection{NDV AD2141 Increases of FasL in Cancer Cell Lines}

The levels of FasL in the cell lines treated with strain AD2141 were determined (Table 3).

Table 3. Concentration of FasL in cancer cell lines treated with NDV AD 2141

\begin{tabular}{|l|lc|}
\hline Cell lines & \multicolumn{2}{|l|}{ FasL concentration $(\mathrm{pg} / \mathrm{ml})$} \\
& Treated cells & Untreated cells \\
\hline RD & 62.5 & - \\
\hline AMN-3 & - & - \\
\hline AMGM & 31.25 & 15 \\
\hline
\end{tabular}

-No activation

It was noticed that there was a significant elevation in the FasL level of human cancer cell lines, $\mathrm{RD}$ and AMGM, when compared with untreated cells; it was $62.5 \mathrm{pg} / \mathrm{ml}$ and $31.25 \mathrm{pg} / \mathrm{ml}$ in virus-treated cells, RD and AMGM respectively. Whereas there is no detectable level of FasL in virus-treated murine cells AMN-3.

\section{Discussion}

Newcastle disease is seriously high contagious disease of birds affecting many domestic and wild avian species (Yi \& Liu, 2011). The major disease signs are respiratory distress, diarrhea, circulatory disturbances, and impairment of central nervous system (Lin et al., 2003). The causative agent of this disease is Newcastle disease virus (NDV) also known as avian paramyxovirus type-1 virus (APMV-1) (Li et al., 2010). Based on the severity of disease, NDV isolates can be grouped into three pathotypes: lentogenic is a mild or in apparent respiratory infection of chickens, mesogenic is an acute respiratory and sometimes lethal nervous infection of young chicks, and velogenic which is a very acute and lethal form of Newcastle disease with hemorrhagic lesions (Choi et al., 2008; Boucher et al., 2010; Cattoli et al., 2011). Our results confirmed the virulence level of NDV Iraqi strain AD2141, it was velogenic type as described previously (Al- Shammary, 2003), and it caused hemorrhage in the skin and death of chicken embryos after $48 \mathrm{hrs}$ from infection. Moreover, this strain had an inhibitory effect on cancer cell lines and it was titer - dependent manner. The cytotoxicity against cancer cells AMN3 and RD was efficient whereas high level of virus titer $(512 \mathrm{HAU} / \mathrm{ml})$ was showed low toxicity against proliferation of AMGM. Indeed, the variations in sensitivity of cancer cells may depend on the differences in the genetic constitutions of these cells (Fabian et al., 2007). Nevertheless, NDV was considered as oncolytic virotherapy for human cancers throughout killing cancer cells by inducing apoptosis. Thus in the present study, comet assay was carried out to investigate the potential role of NDV AD2141 for induction DNA strand breaks as DNA fragmentation in treated cell lines and leading them to death. The results showed that this virus had a significant genotoxicity against cancer cells, it caused DNA fragmentation which expressed as an increasing in the length of DNA migration and appeared as fluorescent head and tail DNA 
fragments from nucleus (Fig.5). This may suggest that NDV exerts its apoptotic activity by induction of other apoptotic proteins upstream of mitochondria leading to DNA fragmentation (Molouki \&Yusoff, 2012; Restifo, 2000). Moreover, this work was included the role of oncolytic NDV Iraqi strain in activation FasL, as extrinsic pathway of apoptosis in treated cancer cell, RD, AMN-3, and AMGM. Our finding confirmed the ability of this strain to stimulate FasL by increasing the concentration level of soluble FasL in human cancer cell lines, AMGM and RD, whereas no detectable activation was noticed in murine cancer cell line AMN-3. This may suggest that the expression of FasL may depend on the origin of tumor cells. Indeed, cyclic variation in the expression of FasL was seen in cells of both mouse and human origin, suggesting that this represents an important means of regulating FasL production for cells (Jamal et al., 2012).

\section{Conclusion}

According to the virulence level of NDV Iraqi strain AD2141, this strain can be considered as a velogenic type. Regarding the cytotoxicity results it had an inhibitory effect on cancer cell lines and it was titer - dependent manner. Moreover, it showed genotoxicity against cancer cell lines via induction DNA fragmentation and activation the level of FasL particularly in human cancer cell lines.

\section{Acknowledgment}

We wish to express our gratitude and appreciation to the staff of Iraqi Center for Cancer and Medical Genetic Research for their support and assistance throughout the duration of this project.

\section{References}

Al- Shammary, A. M. (2003). Study of Newcastle Disease virus effect in the treatment of transplanted tumors in mice. M.Sc. Thesis, College of Veterinary Medicine. University of Baghdad, Iraq.

Apostolidis, L., Schirmacher, V., \& Fournier, P. (2007). Host mediated anti-tumor effect of oncolytic NDV after locoregional application. Int J Oncol, 31(5), 1009-1019.

Boucher, C. E., Bragg, R. R., \& Albertyn, J. (2010). An alternative method for the establishment of virulence of Newcastle disease virus isolates. Afr J Microbiol Res, 4, 2313-2317.

http://www.academicjournals.org/ajmr/pdf/Pdf2010/4Nov/Boucher\%20et\%20al.pdf

Cattoli, G., Susta, L., Terregino, C., \& Brown, C. (2011). Newcastle disease: a review of field recognition and current methods laboratory detection. J Vet Diagn Invest, 23, 637-656. http://dx.doi.org/ 10.1177/1040638711407887

Choi, K., Lee, E., Jeon, W., Nah, J., Kim, Y., Lee, M., Lee, H., \& Kwon, J. (2008). Isolation of a recent Korean Epizootic Strain of Newcastle Disease Virus from Eurasian Scops Owls affected with severe diarrhea. J Wildlife Dis, 44, 193-198. http://dx.doi.org/content/44/1/193.

Fabian, Z., Csatary, C. M., Szeberenyi, J., \& Csatary, L. K. (2007). P53-independent 
endoplasmic reticulum stress-mediated cytotoxicity of a Newcastle Disease Virus Strain in tumor cell lines. J Virol, 81, 2817-2830. http://dx.doi.org/content/81/6/2817.

Freshney, R. I. (2002). Cell line provenance. Cytotechnology, 39, 3-15. http://dx.doi.org/10.1023/A:1022949730029

Hui-fan, J., Bao-rong, C. H. I., Dong-yun, H. E., Change, L. I., Ning ning, H. U., Wang, K. \& Jin, N. Y. (2013). Antitumor effects of Newcastle Disease Virus hemagglutinin-neuraminidase used as a molecular adjuvant. Chem Res Chin Univ, 29(2), 270-274. http://dx.doi.org/10.1007/s40242-013-2391-5

Jagetia, G.C., \& Rao, S. K. (2011). Assessment of radiation-induced DNA damage by Comet assay in cultured HeLa cells treated with guduchi (Tinospora cordifolia Miers) before exposure to different doses of $\gamma$-radiation. Res Pharma Biotechol, 37, 93-103. http://www.academicjournals.org/RPB

Jamal, M. H., Chn'g, W. C., Yusoff, K., \& Shafee, N. (2012). Reduced Newcastle disease virus-induced oncolysis in a subpopulation of ciplatin- resistant MCF7 is associated with survivin stabilization. Cancer Cell International, 12, 35-42. http://dx.doi.org/10.1186/1475-2867-12-35

Kaleta, E. F., \& Baldauf, C. (1988). Newcastle disease in free-living and pet birds. In: D.J. Alexander (Ed.), Newcastle Disease (PP.197-246). Boston: Kluwer Academic Publishers.

Li, Z., Li, Y., Chang, S., Ding, Z., Mu, L., \& Cong, Y. (2010). Antigenic variation between Newcastle disease viruses of goose and chicken origin. Arch Virol, 155, 499-505. http://dx.doi.org/10.1007/s00705-010-0610-7

Lin, M. Y., Liu, H. J., \& Ke, G. M. (2003). Genetic and antigenic analysis of Newcastle disease viruses from recent outbreaks in Taiwan. Avian Pathology, 32, 345-350. http://dx.doi.org/10.1080/0307945031000121086

Mayo, M. A. (2002). A summary of taxonomic changes recently approved by ICTV. Arch Virol, 147, 1655-1663. http://dx.doi.org/10.1007/s007050200039

McGinnes LW, Pantua H, Reitter J, \& Morrison TG. (2006). Newcastle disease virus: propagation, quantification, and storage.Curr Protoc Microbiol, Chapter 15: Unit 15F.2. http://dx.doi.org/ 10.1002/9780471729259.mc15f 02s01

Molouki, A., \& Yusoff, K. (2012). NDV-induced apoptosis in absence of Bax; evidence of involvement of apoptotic proteins upstream of mitochondria. Virol J, 9, 179-182. http://dx.doi.org/10.1186/1743-422X-9-179

Nandhakumar, S., Parasuraman, S., Shanmugam, M. M., Ramachandra Rao, K., Chand, P., \& Bha, V. (2011). Evaluation of DNA damage using single-cell gel electrophoresis (Comet $\begin{array}{llll}\text { Assay). } & J & \text { Pharmacol } & \text { Pharmacother, }\end{array}$ 
http://dx.doi.org/10.4103/0976-500X.81903

NI, J., Galani, I. E., Cerwenka, A., Schirmacher, V., \& Fournier, P. (2011). Antitumor vaccination by NDV Hemagglutinin-Neuraminidase plasmid DNA application: Changes in tumor microenvironment and activation of innate anti-tumor immunity. Vaccine, 29(6), 1185-93. http://dx.doi.org/10.4103/0976-500X.81903

Phelan, M. (1988). Basic techniques for mammalian cell tissue culture. Current Protocols in Cell Biology, 7, 15-35.

Restifo, N.P. (2000). Not so Fas: Re-evaluating the mechanisms of immune privilege and tumor escape. Nat Med, 6, 493-495. http://dx.doi.org/10.1038/74955

Ryan, A. E., Lane, S., Shanahan, F., O’Connell, J., \& Houston, A. (2006). Fas ligand expression in human and mouse cancer cell lines; a caveat on over-reliance on mRNA data. $J$ Carcinogenesis, 5, 5-11. http://dx.doi.org/10.1186/1477-3163-5-5

Sanchez, A., Espinosa, P., Garcia, T., \& Mancilla, R. (2012). The 19kDa Mycobacterium tuberculosis Lipoprotein (LpqH) Induces Macrophage Apoptosis through Extrinsic and Intrinsic Pathways: A Role for the Mitochondrial Apoptosis-Inducing Factor. Clinical and Developmental Immunol, 2012. http://dx.doi.org/10.1155/2012/950503

Schirmacher, V., \& Fournier, P. (2009).Newcastle disease virus: a promising vector for viral therapy, immune therapy, and gene therapy of cancer. Mothods Mol Biol, 542, 565-605. http://dx.doi.org/10.1007/978-1-59745-561-9_30

Schirmacher, V., Bai, L., Umansky, V., Yu, l., Xing, Y., \& Qian, Z. (2000). NDV activates macrophages for anti-tumor activity. Int J Oncol, 16(2), 363-373.

Stover,E. (2002). In vitro cytotoxicity of the epothilone analog, BMS 247550, in pediatric malignacies. Cantaurus, 10, 31-37.

Xu-Dong, L., Xiao-Lan, Z., Cheng, C., Guang-Bo, Z., Xue-Guang, Z., \& Jian-An, H. (2009). Inhibition of lung cancer cell proliferation by CD40 signaling through tumor necrosis factor I. Chinese J Cancer, 28(1), 20-23. http://www.cjcsysu.com/ENpdf/2009/1/20.pdf.

Yi, J., \& Liu, C. (2011). Detecting Newcastle disease virus in combination of RT-PCR with red blood cell absorption. Virol J, 8(202), 1-5.

\section{Copyright Disclaimer}

Copyright reserved by the author(s).

This article is an open-access article distributed under the terms and conditions of the Creative Commons Attribution license (http://creativecommons.org/licenses/by/3.0/). 